\title{
Luis Solís*
}

\section{PAZ'S A DRAFT OF SHADOWS: REWRITING THE PAST, THE PRESENT AND THE SELF}

\begin{abstract}
Pasado en Claro (A Draft of Shadows) was first published in 1975. This long poem is the mental journey Paz embarks upon in pursuit of his own personal paradise. This article focuses on three of important concepts Paz explores in this poem and in his literary output as a whole: the scope of language, memory and otherness. In the case of language, and its expression in poetry, Paz's most eloquent pages can be found in The Bow and the Lyre (1956), but especially in The Monkey Grammarian (1970), the account of another journey, through language and the acts of writing and reading. As a personal attempt at regaining a mythical past, A Draft of Shadows affords a view of both the vast narrative of Mexican history and Paz's personal retelling of his own past. A journey like this is only possible via the winding path of memory, its expression in language, and an identity created as it follows its own trail.
\end{abstract}

Keywords. Octavio Paz; A Draft of Shadows; language; memory; otherness.

In his introductory anthology to Paz's literary output, Cayuela Gally (2008) describes A Draft of Shadows as a "central poem in Paz's poetics and language, a sort of autobiography in verse that also forms one of the poles of Paz's poetry, the other being "Sunstone'" (18). An epigraph, a few verses quoted from Wordsworth's "The Prelude", precedes A Draft of Shadows: "Fair seed-time had my soul, and I grew up/Fostered alike by beauty and by fear" (I, 265-66).

\section{A journey into memory and its abysses}

From this is apt departure point, Paz embarks on his own journey into the depths of memory and its recovery:

Heard by the soul, footsteps

*Universidad Autónoma del Estado de México (UAEMEX); Mexico. 
Re-writing, Re-imagining the Past (IV)

in the mind more than shadows,

shadows of thought more than footsteps

through the path of echoes

that memory invents and erases:

Right from the onset, Paz admits several things. 1. These footsteps are not physical, and are even devoid of the immateriality of a shadow. 2. The sound made by his footsteps are shadows of real footsteps, mere echoes. 3. Memory erases these footsteps, no sooner invented.

The poet walks on, an action that happens in time, reduced to an evanescent present. This reminds us of The Monkey Grammarian, where Paz says that "fixity is always momentary" (17).

Like drizzle on embers,

footsteps within me step

toward places that turn to air.

Names: they vanish

in a pause between two words.

In correspondence with Pere Gimferrer, Paz concedes that there are similarities between The Monkey Grammarian and Draft of Shadows:

Poems, like "Pasado en claro" ${ }^{2}$ and others you don't know stem from a different sort of inspiration. "The themes" and concerns, however, are the same. The idea is to arrive at the same destination, but through a different path (A point that, regardless of our destination, we never reach). (Gimferrer 105)

A Draft of Shadows emphasizes its own ceaseless process of creationdestruction. Together with Paz, we reach an ever-widening chasm between memory and language:

The sun walks through the rubble

\footnotetext{
${ }^{2}$ I retain the name in Spanish, as there was no Spanish version of the poem at the time Paz wrote to Gimferrer. Unless otherwise stated, the passages from books in Spanish quoted here are my own translations.
} 
of what I'm saying; the sun

razes the places as they dawn,

hesitantly, on this page;

the sun opens my forehead, balcony

Perched within me.

\section{An important nuance and other abysses}

In his otherwise impeccable English rendition of the original Spanish, Weinberger omits 'voladero', meaning 'ravine' or 'precipice', thus failing to notice that Paz's balcony overlooks a ravine, a metaphor highlighting the hazards that the journey entails. This omission - barely significant in the overarching scope of the poem - deprives the text of a symbol that reappears under various guises: as a well, for instance, another metaphor of the tectonics underpinning this journey. The abyss is a summary of Paz's poetics and his concept of language:

Nothing do I love more than verbal perfection, but only if that language suddenly cracks open and, in so doing, we see and hear in that abyssal rupture - literally abyssal - another reality. A reality that we did not know and a voice we had only in heard in dreams. The voice we had wanted not to hear: the voice of death, a carnal voice. (Paz, También soy 112)

The path becomes rugged and stony, and the poet inches along on the precariousness of a terrain, suitable for goats and other such creatures thriving memoryless - on the edges of ravines. A black wave of syllables sinks "its ink roots in the subsoil of language", snaking its way on the surface of the page. The tone is confessional: "I drift away from myself". This paradoxical journey takes the poet to himself, while simultaneously forcing him away from himself. This is akin to some form of archaeological search, where the poet unearths his own identity covered by layer upon layer of time, memory and history. The only tool at his disposal is ineffectual language:

Criticism of the language is an active operation that means digging into the language to discover what is hidden there: the worm-eaten foundations of institutions, the mire of the subsoil, the slimy creatures therein, the endless underground galleries. (Paz, The Other 50) 
Later we see Paz setting out from his forehead toward an instant of clarity: "a brief bifurcation of thought", where the centuries that took a banyan tree to grow, on "the vertical patience of a wall", are but mere seconds. Words such as 'here' and 'there' no longer make any logical sense. Paz and the reader can only reach this noon by transcending the limits of doubt, by "glimmers and mirages, where language recants".

Paz reaches an old patio, threatened "by writing and its uncertainties". Paz ambles through the images captured by "an eye that has lost its memory". In his excavation, Paz has reached a layer of myth: the odd mushroom becomes "a vegetable Mithridates", and a harmless newt has the "fiery breath", of a chimera.

I am inside the eye: the well where,

from the beginning, a boy is falling,

the well of the account of my account.

Paz tells us this, and he is simultaneously told: "the account of my account". The well is the meeting point of past and present: "where the water rises and my shadow falls". It is also a caveat about the limits of language and the inaccuracies of memory.

Then we reach one lower stratum in the excavation: the lagoon upon which the ancient Mexica capital, Tenochtitlan, once stood. The ancient city is soaked in blood. The quality of the light renders the scene ablaze. In the midst of this conflagration, the poet's pencil refuses to write on:

My pencil rebels against dictation.

The lake is eclipsed

by the writing that names it,

I fold the page.

\section{A digression on naming}

The naming of the lagoon, enmeshed in grammar and syntax, spoils its pristine quality as a myth. Paz is one of those poets that have lost faith in the powers of language.

It is just those "tellers of the tale" who are most dubious of language, who are most economical with its fallible, shop-worn usages - a Kafka, a Beckett - who seem most honest, whose abstentions form certitude cut the 
deepest. (Steiner 198)

Paz concludes that the impossibility of things having a proper name stems from our exile from Paradise. The freezing of time and the cancellation of change hark back to a mythical past.

This is our eternal damnation, ours and the world's. And this is what Christians mean when they speak of the state of fallen nature. Paradise is governed by an ontological grammar: things and beings are its names and each name is a proper name. (108)

Utterance and texts are sequential, they happen one after the other. This may be a cycle or a line moving forward, the fact remains that one event follows another. In The Double Flame, Paz uses this idea of deterioration to comment on the decay of language.

Although a Judeo-Christian myth, Adam and Eve have counterparts in other religions. They live in paradise, a place that is not beyond time, but at its beginning. Paradise is what has been before; history is the deterioration of primordial time, the fall of the eternal present into succession. (272)

Before our fall, we lived in a mythical past when change did not exist, nor did renovation and death, and names were precise. Barring the likes of Adam, nobody has ever called things their proper name. Paz next says:

We live among names;

that which has no name

still does not exist:

Adam of mud,

not a clay doll: a metaphor.

To see the world is to spell it.

We return to the liquid images of the well, whose water reflects images expressed through language:

Mirror of words where was I?

My words watch me from the puddle 
of my memory ...

Rippling shadows, flashes, echoes,

the writing not of signs, but of murmurs.

The words Paz uses take us back to the point of departure: 'shadows', 'echoes', 'murmurs'. Upon reaching this depth in his quest, Paz asks "Where was I?" The question admits only one answer:

I am where I was:

within the indecisive walls

of that same patio of words.

\section{A few strata below}

Paz reaches the depths where he encounters his childhood friends, the primordial fig tree, the human body and its language, a sum of "revelations and abominations". We are back in Paradise: "thousands of leaves, "the hummingbird's flash", and desire running wild in the profuse vegetation. His archaeology takes him to the furthest reaches of sight:

The crack in the tree trunk:

sex, seal, serpentine, passage

closed to the sun and to my eyes,

open to the ants.

The crack in the tree trunk is a riotous world of greenery, a palpable universe "where to touch is to see", fingertips are eyes, and everything else is its exact opposite. It is Paradise itself: no school, and time is yet to be invented:

The sun has not grown old,

this snow is the same as grass

always and never the same,

it has never rained, it always rains,

everything is being, and has never been.

This is the kind of time Paz imagines in Seeds for a Hymn: absolute harmony between language and the world: 
Re-writing, Re-imagining the Past (IV)

The dominant point of view in this book is essentially utopian: the intuition of an original time - a time without time or that is all time - in which man lived in complete harmony with other men and with the universe; a language which was the perfect representation of the universe corresponded to this social and cosmic harmony, and the intuition of that kind of "Golden Age". (Ivask 10-1)

\section{A note on the Spanish original and other precisions}

In the Spanish original, "Pasado en claro" means clarification, writing a second draft in the most precise language, whose function, according to Gullón (1972) is no other than salvation:

The Arc and the Lyre ${ }^{3}$ is an attempt to clarify the problem posed by this function ... And in the final chapter of what is definitely a poetics, it is not surprising to find ... observations, not at all extemporaneous, on poetry as an instrument of salvation. (592-3)

Trying hard not to exaggerate, Gullón goes on to quote directly from Paz's essay, where the poet sets great store by accurate language:

The impossibility of communicating with others is, of course, based on the impossibility of making ourselves clear to ourselves, of knowing who speaks to whom when man speaks alone and by himself. (593)

The precondition for communication is clarity. Curiously enough, Weinberger translates Pasado en claro as A Draft of Shadows, which is more precise than it may seem: an attempt to shed light on a life.

\section{Abolishing time}

Like the Alice of another tale, Paz has landed on a kingdom beyond the strictures of time, and the decay it entails:

pitiless transparencies, cages of clarity, where identity cancels itself in its likenesses.

Difference in its contradictions.

\footnotetext{
${ }^{3}$ The Bow and the Lyre.
} 
It has never rained, it always rains,

everything is being, and has never been,

a nameless people of sensations,

names that search for a body,

With the abolition of time, everything exists in a perpetual present -in a present participle. Paz gazes at the truthful transparency of everything:

The fig tree its lies and its wisdom:

wonders of earth

-trustworthy, punctual, redundant.

Paz claims that a year is a sequence formed by "changes that are repetitions". At dawn, mists gradually disappear to let in the clarity of day. Soon, it is dusk again; one stanza later, it is night. The poet is in the old family house, the stratum of his education as a teenage reader. Paz is in the midst of the countless books he read in his adolescence, "transparent fever machines, architectures built above an abyss". Paz sheds a tear before the pyre of the horsetamer, ambles in Garcilaso's grove, and feels the pangs of thirst in the Gobi Desert. These are also the shelves of "the books marked with the arms of Priapus".

Next, Paz takes us to 'Casa grande'. The big house, and the surrounding landscape, never changes: a place "stranded in clogged time":

The years turn in the plaza,

a Catharine wheel,

and do not move.

In describing the old house, Paz notices that his words "crack" ("se agrietan"), which is more precise than what Weinberger translates as "split apart". Here Paz comes to terms with his own family, and revisits his mother, whom he describes as "a love letter with spelling mistakes".

'Days' is the word that ushers in another passage. Paz tells us that God never talked to him. What did was his own body, his "many bodies", in the form of a lesson learnt from the leaves of a fig. Of an afternoon, Paz experiences "instantaneous incarnations". This is an eternal instant where time remains immobile while moving: 
- As if time at last were to coincide

with itself, and I with it,

as if time and its two times

were one single time

that still was not time, a time

where always is now and anytime always,

as if I and my double were one

and I was no longer.

The Catharine wheel mentioned before spins while remaining static, a perpetual present participle: being. This paradoxical time is the erotic climax Paz experiences. Later on, Paz unveils an open secret, whose truth he summarises in this lapidary conclusion: "There are no dead, there is only death, our mother". No sooner formed, things vanish. Paz claims that "Death is the mother of forms", another metaphor to refer to language and writing, and their shortcomings. While having completed one more leg on this journey, we seem to have reached an earlier stage. Written or uttered, words fail to convey our intended meanings:

I write death and for a moment

I live within it. I inhabit its sound:

a pneumatic cube of glass,

vibrating on this page,

vanishing among its echoes.

\section{Language and other shortcomings}

Dexterous as great poets might be, they sometimes fail miserably at expression. In the case of Paz, the house, the ruins, and his quest translate as lines composing a text:

Landscape of words:

my eyes, reading, depopulate them.

It doesn't matter: my ears propagate them.

They breed there, in the indecisive

zones of language, the villages in the marsh.

Once consumed by our reading, words escape the conflagration, standing 
in marshy land: "the indecisive zones of language", where they live on as echoes in the chambers of the mind:

They are amphibious creatures, they are words, they pass from one element to another, they bathe in fire, rest in the air.

They are from the other side.

In their transit from a means to another, words can only cover so much meaning. Paz cannot hear them though; they are $o n^{4}$ the other side:

I don't hear them: what do they say?

They don't say: they talk, talk and talk.

Paz walks on, "on a suspension bridge of eleven syllables". Next, he talks about moths and butterflies, phantoms in thrall of an electric bulb. Paz describes a scene of his childhood: women crying at unison at the sight of a "Cabeza de muerto" 5 , a moth, traditionally associated with death. "Are there messengers?" Guadalupe Nettel says that Paz considers speech as "a particular expression of a natural condition, and human speech is but one of the dialects of the linguistic systems of the universe" (111). He then adds:

Animals and things make languages,

through us the universe talks with itself.

We are a fragment-

accomplished in our unaccomplishment-

of its discourse ...

what does it say? It says that it says us.

Explicitly now, Paz discusses language and its limits. Eco (2003), drawing on Hjelmslev, says that the human languages segment that "pre-linguistic continuum", which we may call "reality", "the universe", or "the world". Each language covers only a portion of reality ("we are a fragment"), but each fulfils the needs of its speakers, and allows them write poems about one's history and identity. Our reality is a "fragment accomplished in its unaccomplishment". The

${ }^{4}$ Not from the other side, as Weinberger translates.

${ }^{5}$ Acherontia atropos. 
perfect agreement between a word and its content may be irretrievable. Paz's "Seeds for a Hymn", according to Ivask, is a text about the lost powers of language:

If then, according to this poem, poetry is condemned to fragmentation, it also seems destined to the evocation of the original Word, that "immense and total word." Although inexpressible, it alone makes it possible for the poet to say what he says. The entire book is organized around that Word: not as a presence, certainly, but as an absence. (11)

As we cannot transcend our own expression, every utterance is doomed to be a reiterative solipsism, a shadow of ourselves. However, the 'us' we utter is not the real 'us', but the vehicle through which we apprehend reality. Paz asks what the solipsism says. "It says that it says us" is his answer: a mirror image reflected on a mirror. It would not be a blatant violation of logic to say that any utterance is and is not what we say. In this part of the poem, Paz quotes Shakespeare's Troilus and Cressida:

It says that it says us.

It says it to itself. Oh madness of discourse,

that cause sets up with and against itself!

According to Miller, the above passage eschews the very foundation of logical thought:

The principle of identity is ... the order, finally, of language, of rational discourse which posits unified entities and names as what they are. The "whole shebang" of Occidental metaphysics is ... brought into question in Troilus' experience and in his speech. (47)

Things want, according to Paz, "to always be more than more". This is a form of punishable injustice. We are sentenced to live in history, to become past, in a sequence of events leading to our utter demise:

To be time is the sentence; history, our punishment.

Tunnels, galleries of history:

is death the only exit? 


\section{In search of a way out}

Paz suspects that we should look no further; the answer to that question lies within ourselves: the way out is the way in.

The way out, perhaps, is toward within.

The purgation of language, history consuming itself

in the dissolution of pronouns:

not I am nor I even more so

but more being without I.

One way out of the crisis lies in the negation of discrete identities. Paz is convinced that the ' $\mathrm{I}$ ' than can say ' $\mathrm{I}$ ' (as in ' $\mathrm{I}$ am') necessarily implies the presence of countless other beings. That is the essence of 'otherness' ${ }^{6}$, which is at the core of Paz's universe:

Duality is not something added, artificial or exterior: it is our constituent reality. Without otherness, there is no oneness ... Otherness is the projection of oneness: the shadow with which we battle in our nightmares. (Paz, The Other 75)

In his archaeological search for himself, Paz recognises that he is the son of various actors that shape his identity. Xavier Rodríguez Lesama says this about otherness in Paz:

Such an intercultural vision as the basis for the historical and sociological analysis of Mexico rests precisely on this point: recognizing otherness, a concept that Paz proposed as a means to understand ourselves in $1950 \ldots$ $\mathrm{He}$, more than anyone else, understood with perfect clarity and fully recognized and value the horizons with which he endowed his reflection:

\footnotetext{
${ }^{6}$ In Piedra del sol (Sunstone), we find this celebrated passage, in Eliot Weinberger's translation about identity, Paz's and everyone's.

For me to be I, I must be another, emerge from myself, search for myself among the others, the others that are not if I do not exist, the others that give me full existence, I am not, there is no I, we are always us.
} 
Re-writing, Re-imagining the Past (IV)

otherness as his astrolabe. (244)

Amidst the greenery of the patio, Paz sees "a fortuitous meeting of reflections". The walls that form the patio are not made of stone; they are walls of memory, and as such, they form a transitory grove.

The bodiless god, the nameless god

whom we call by empty names-

by the names of emptiness -

the god of time, the god that is time, passes through the branches

that I write.

In the peace and quiet that the old house affords, Paz reaches a conclusion about time and memory and their effects on our being:

Tranquility dissolves in itself. Time

elapses without elapse. It passes and stays. Perhaps

although we all pass, it neither passes nor stays:

there is a third state.

This third state is one that allows opposites to coexist, the realm of the oxymoron:

A third state:

being without being, empty plenitude,

We are, once more, in the "indecisive zones" of language, where utterance is an inane effort at expression. In this third state, we look for essences, and presences, only to find a 'presentiment', a vague feeling, and a fleeting memory that vanishes into thin air the moment we talk about it:

The names that name it say: nothing.

Double-edged sword between two hollows.

Its house, built on air

Paz realizes that his journey down the depths and recesses of his being is inexorably doomed: "between two hollows". Words are flimsy constructions of 
air, fire, and water. He must accept an unassailable truth: everything he remembers or says is inaccurate at best. This, obviously, includes God. The being of God (and of all other beings for that matter) is elusive by nature. In this kingdom of the ineffable, concepts such as 'same' are utterly devoid of meaning. Paz has an impending sense of foreboding looming on the horizon. Therefore, whatever had become clear in this recounting is lost:

it was the eclipse of the clarities.

It appeared in every form

of vanishing.

"Bodiless god", says Paz in the following part of the poem. If only through our body can we have an inkling of God, as there is no word that can accomplish that declarative feat, God - together with all the other beings - is irretrievably lost beyond the opaqueness of words.

Bodiless god,

my senses named it

in the languages of the body.

I wanted a solar name,

a word without reverse.

In his retelling of his times and life, Paz is looking for a coin without a contradictory reverse. Like Rabbi Loewe in Prague, he is on a quest for the precise combination of the letters that form the real name:

I exhausted the dice box and ars combinatoria.

A rattle of dried seeds,

the broken letters of names:

we have crushed names,

we have scattered names,

we have dishonoured names.

Since then, I have been in search of the name.

The mood cannot be gloomier: words have exhausted their generative powers and become sheer noise. Of this, these times of "alternate facts" provide plenty of evidence. This Paz's lament in The Other Mexico (1972): 
The loathsome vulgarities of advertising - all that asphyxiating rhetoric, that sugary, nauseating rhetoric, of satisfied people whose gluttony has made them lethargic. Seated at Mexico, the new lords and their courtesans and parasites lick their lips over a gigantic platter of choice garbage. When a society decays, it is language that is first to become gangrenous. (48)

Despite the rampant decay and corruption of language, Paz soldiers on in his search of the name:

I followed a murmur of languages, rivers of between rocks color ferrigno of these times.

Pyramids of bones, rotting places of words: our masters are garrulous and blood thirsty.

Paz takes us to Dante's Inferno, to a place called the Malebolge, with its deep chasm the colour of rust. This is the tomb of words, where stacks of words ("pyramids of bones") haphazardly lie about emptied of substance. With the shadows of these useless tools, the poet redrafts his past:

I built with words and their shadows

a movable house of reflections,

a walking tower, edifice of wind.

There are countless versions of a poem that have joined the ossuary of many others. We find combinations of every possible sequence and configuration. The order is immaterial, as the parts amount to dissolution, echoes and air:

Time and its combinations:

the years, and the dead, and the syllables,

different accounts from the same account.

Spiral of echoes, the poem

is air that sculpts itself and dissolves,

a fleeting allegory of true names. 
Paz says "spiral", precisely the word he used in describing this poem. In a letter to Gimferrer, Paz says that A Draft of Shadows, "in more ways than one, is a return -though not to the point of departure, I hope... It is a return similar to that of a spiral. That, at least, is what I set out to do" (93).

On some fortunate occasions, a poem comes to life. For a short instant, we can perceive just a semblance of meaning and sense on the printed page:

At times the page breathes:

the swarm of signs, the errant

republics of sounds and senses,

in magnetic rotation

link and scatter

on the page.

At the end of the poem says "I am where I was". To the dismay of many non-native speakers, Spanish has two separate verbs: 'ser' and 'estar'; the former refers to essences, to permanent features; the latter, to the temporary. Therefore, the first line of the last part of the poem refers to the state Paz is in as he speaks, but also to his essence, but only if we believe that an essence can be contained in a sentence:

I am where I was:

I walk behind the murmur,

footsteps within me, heard with my eyes,

the murmur is in the mind, I am my footsteps,

I hear the voices that I think,

the voices that think me as I think them.

\section{Conclusion}

The last line is the outcome of his efforts at redrafting the account of his own history. In their simplicity, the words Paz uses to describe himself are indeed honest, but just as sobering: "I am the shadow my words cast."

This is a synthesis of Paz's journey into the abysses of his life through the defective mirrors of memory and language.

\section{Works Cited}


University of Bucharest Review $\propto$ Vol. XI/2021, no. 2 (new series)

Re-writing, Re-imagining the Past (IV)

Gullón, Ricardo, and Tom J. Lewis. "The Universalism of Octavio Paz." Books Abroad, vol. 46, no. 4, 1972: 585-95. JSTOR, www.jstor.org/stable/40126504. Accessed 1 June 2021.

Ivask, Ivar. The Perpetual Present: The Poetry and Prose of Octavio Paz. Norman, OK: U of Oklahoma, 1975. Print.

Ledesma, Xavier Rodríguez. "To Hear the Inaudible, To See the Imperceptible: Modernity and Otherness in Octavio Paz." Humanism and Critique (2009): n. pg. Web.

Miller, J. Hillis. "Ariachne's Broken Woof". The Georgia Review, vol. 31, no. 1, 1977: 44-60. JSTOR, www.jstor.org/stable/41397442. Accessed 1 June 2021.

Nettel, Guadalupe, and Eduardo Berti. Octavio Paz: Las palabras en libertad. México, D.F.: El Colegio de México, 2014. Print.

Paz, Octavio, and Eliot Weinberger. A Draft of Shadows, and Other Poems. New York: New Directions, 1990. Print.

---. El arco y la lira. México, D.F.: Fondo De Cultura Económica, 1986. Print.

---. The Bow and the Lyre (El arco y la lira). The Poem. The Poetic Revelation. Poetry and History. Trans. Ruth L. C. Simms. Austin, London: University of Texas Press, 1973. Print.

----. The Double Flame: Love and Eroticism. Trans. Helen Lane. New York: Harcourt Brace, 1995. Print.

---. La Llama doble: Amor y erotismo. México: Seix Barral, 2006. Print.

---. The Monkey Grammarian. Trans. Helen Lane. New York: Arcade, 2005. Print.

---. El Mono gramático. Barcelona: Galaxia Gutenberg, 1998. Print.

---. and Pere Gimferrer. Memorias y palabras: Cartas a Pere Gimferrer, 1966-1997.

México: Editorial Planeta Mexicana, 2018. Print.

---. Por Las Sendas De la memoria: Prólogos a una obra. México: Fondo de Cultura Económica, 2011. Print.

---. and Julio Hubard. También soy escritura: Octavio Paz cuenta de sí. México, D.F.: Fondo de Cultura Económica, 2014. Print.

---. and Eliot Weinberger. Sunstone = Piedra de sol. Trans. Eliot Weinberger. New York: New Directions, 1991. Print.

---. The Labyrinth of Solitude; And, the Other Mexico; Return to the Labyrinth of Solitude; Mexico and the United States; The Philanthropic Ogre. Trans. Lysander Kemp. New York: Grove, 2001. Print.

---. and Ricardo Cayuela Gally. Las Palabras y los días: Una antología introductoria. México D.F.: Consejo Nacional para la Cultura y las Artes, 2008. Print. 
---. The Other Mexico: Critique of the Pyramid. Trans. Lysander Kemp. New York: Grove, 1972. Print.

Steiner, George. After Babel: Aspects of Language and Translation. New York, London: Oxford University Press, 1995. Print. 